International Journal of Instruction e-ISSN: 1308-1470 • www.e-iji.net

Article submission code: 20191201170323

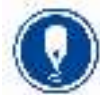

January $2021 \bullet$ Vol.14, No.1

p-ISSN: 1694-609X

pp. 303-324

Received: 01/12/2019

Revision: 22/06/2020
Accepted: 12/07/2020

OnlineFirst:18/10/2020

\title{
Educational Imitation of Basic Job Function Using the Knowledge of English among Technical Major Students
}

\section{Irina Kotlyarova}

South Ural State University, Russia, kotliarovaio@susu.ru

\author{
Anna Chuvashova \\ South Ural State University, Russia, anna.chuvashova25@gmail.com
}

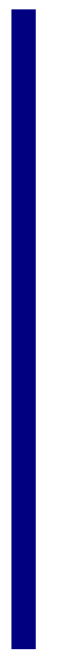

\begin{abstract}
This study explores how English for specific purposes can be effectively introduced into the training of technical major students to form profession-related skills. Students were provided with an opportunity to introduce acquired language skills into their future professional career when performing such professional task as the development of design and technological documentation which is a real and basic job function. The course was developed on the basis of the interdisciplinary approach to improve the level of integrated knowledge and skills to perform the stated job function. Five groups of fourth-year students consisting of 110 people of Aerospace faculty in South Ural State University took part in the experiment. The course includes interdisciplinary tasks and practice. Before and after the implementation of the course students were assigned the same test and their level of integrated knowledge and skills was measured. A statistical method of applying the Rosenbaum Q criterion to compare and evaluate the data was used. Results show that the level of 3 out of 5 types of integrated knowledge and skills has risen significantly which indicates students' readiness to perform the stated job function. The suggested course can be introduced into an educational process teaching technical major students.
\end{abstract}

Keywords: job function, professional environment, interdisciplinary approach, development of design and technological documentation, English for specific purposes

\section{INTRODUCTION}

Professional standards on vocational education contain such requirements as the readiness to participate in the work of international teams to address scientific and educational issues and objectives. Such membership for promoting vocational education and training as Worldskills International include such requirements as the ability to collaborate with work colleagues effectively which maximizes performance efficiency, the ability to share knowledge and expertise with colleagues. Roadmaps for the competitiveness enhancement programmes of many Russian universities include strategic goals of global leadership, integration of students and faculty into an

Citation: Kotlyarova, I., \& Chuvashova, A. (2021). Educational Imitation of Basic Job Function Using the Knowledge of English among Technical Major Students. International Journal of Instruction, 14(1), 303-324. https://doi.org/10.29333/iji.2021.14118a 
international community, achievement of globally recognized scientific breakthroughs in different fields of specialization. Educational programs for technical major students should be developed according to the requirements presented in professional standards (Khairutdinov et al., 2019).

Preconditions for our research are studies that investigate the use of English for professional purposes (Fiorito, 2019); studies that introduce the application of project methods, case-study to imitate job functions in the educational process (Isoc \& Surubaru, 2020). Moreover, there are many investigations done in the sphere of application of professional English to an academic curriculum of non-linguistic major students which helps find solutions to different professional problems (Mulyadi et al., 2019; Fiorito, 2019; Smagulovaet al., 2019; Anthony, 2018; Woźniak, 2017; Ph'ng et al., 2016; Yemelyanova et al., 2016; Yelubayeva et al., 2016; Salehi et al., 2015; ArnóMacià \& Mancho-Barés, 2015; Coleman, 2006). Researches tend to focus on various professional issues solved by means of effective foreign language teaching (Tarasova, 2016). Professional culture taught by English for specific purposes can be one of the cases of problem based approach focused on investigating peculiarities of a specific field (Semchuk et al., 2019). Studying English students take part in global cultural and professional communication. We have already researched the ways how to implement project work in the educational process to develop students' professional competences to perform research and development $(\mathrm{R} \& \mathrm{D})$ and manufacturing tasks (Voloshina \& Kotlyarova, 2017; Grevtseva et al., 2019).

Despite the various research, there is still an unsolved problem how to develop universal integrated knowledge and skills that will form a professional competence. Nowadays an engineer uses a knowledge system mastered in the study of many disciplines: universal, general, special ones to solve professional problems and perform job functions. The key to successful professional work is gained and developed necessary competencies. Educational programs are based on matrices of competencies that show that the development of one particular competence depends on the study of several disciplines mastered simultaneously or sequentially, although a disciplinary approach is still widely used in educational programs today. As a rule teachers focus only on their own disciplines and do not take into considerations the subject matter of other disciplines studied by their students. Teachers from different departments do not collaborate when it comes to teaching independent disciplines. The use of a disciplinary approach becomes an obstacle to the formation of a professional competence. As practice shows, according to the survey conducted among teachers from technical departments of Russian universities more that $60 \%$ of students are unable to perform professional tasks that require integrated knowledge consisting of foreign language literacy and professional skills. We assume that the solution to this relevant problem is the introduction of the interdisciplinary approach using the theory of interdisciplinary which will help to synthesize and combine knowledge of different disciplines along with collaborative work of teachers in order to develop tasks to imitate real job functions. Application of the theory of interdisciplinarity helps to solve the following problems: study of one object from the point of view of different disciplines which allows finding information about new properties of the studied object; organization of work of 
specialists of different areas; implementation of applied (practice-oriented) research results (Maletina et al., 2015; Ertas et al., 2000). The theory of interdisciplinarity which combines teaching English and other professional disciplines is being applied and introduced into the educational process. Researches investigate what its benefits are for technical major students. Interest in the theory of interdisciplinarity was established long ago and there are studies that prove the effectiveness of collaboration and cooperation between different teams of students and teachers which brings together technical professional knowledge and conversational language abilities (Rynearson, 2010).

The theory of interdisciplinarity is often applied to the educational process using a communication-oriented approach. The communication-oriented approach being one of the popular approaches to teaching English as a foreign language in general has always been widely used in training future engineers and teaching them English for professional purposes (Bojović et al., 2015). Though this approach is an effective tool of mastering communication skills which later can be applied to any areas in life including a professional sphere as well, this approach does not teach students to use English for any other professional tasks rather than communication. Technical communication becomes a subject of many researches done in the context of teaching English to engineers. Language policy is oriented on the ability to communicate and read special technical literature. Some researches focus on the formation of communicative competence as the main goal studying English for professional purposes (Niyazova et al., 2018). We can say that the interdisciplinary approach is still present in the organization of the educational process, authors speak about professionally-oriented speech which is apparently includes the specifics of students' major and students learn to understand messages and respond to them within a professional context. Authors also make a conclusion that project based learning enables students' oral and written communication skills (Kovalyova et al., 2016).

A communication competence is viewed as basic one when teaching English to future engineers. Students' skills to be able to give presentations are assessed according to such criteria as the correct use of terminology, argumentative language, responses to asked questions, so students' communicative competence can be developed through technical oral presentations (Bhattacharyya \& Zainal, 2015). Some recent researches which are worth mentioning also suggest different effective tools that can be used to improve students' ability to use English in professional situations. Approaches suggested in these researches develop speech skills on a professional context for students to acquire meta-subject competences (Rybushkina \& Sidorenko, 2015; Singh \& Kaur, 2019); such skills as critical thinking, problem solving, collaboration using a casestudy method (Bhuvaneswari, 2016; Kolomiets et al., 2019); listening skills with the help of profession-based podcasts (Chaikovska et al., 2019); general language skills by means of additional practice using e-learning environment filled with profession-related data (Gluchmanova, 2017). We mention these researches because they summarize the idea of using the theory of interdisciplinarity and prove its effectiveness but they focus solely on a communicative competence. It makes a difference in the way English is taught to future engineers but still these researches primarily aim at developing communication skills within professional context, they study how only English can be 
taught and learned. Compared to these mentioned researches, our study is focused not only on mastering language skills but also on acquiring specific professional skills to perform real professional tasks using the knowledge of English. We think that a communicative competence is not enough for future engineers to be able to solve professional problems. Students should be taught how to perform actual job functions using a communicative competence. A foreign language is not a purpose, it is a means to achieve professional goals which are presented by real job functions.

Numerous professional standards of different technical majors present one job function "Development of design and technological documentation". Development of design and technological documentation is the initial process preceding the manufacture of any product. Work with technological documentation is the first and significant step which defines all the further tasks. The analysis of this job function proves that performance of such work requires a great range of tools and knowledge which can be called universal since they can be applied to different job tasks. Since the development of design and technological documentation is a basic job function that guarantees the performance of other job functions, we introduce the course that contains practical tasks doing which students gain integrated knowledge and skills to perform the chosen job function which consequently means students are getting ready for other possible job functions or professional tasks that require English competency.

\section{LITERATURE REVIEW}

The problem of teaching English to engineering major students has been a problem for a long time; many authors dedicate their researches to this problem (Clement \& Murugavel, 2015; Kim et al., 2018; Wyatt et al., 2018; Kogan \& Krymskaya, 2018; Triawan et al., 2019; Dobrydina et al., 2019; Goldman et al., 2019). Teaching English for specific purposes has two major aspects: identifying the core context relating to the chosen specialty and choosing the right method of teaching which will allow teaching English within the chosen specialty.

The course of English for specific purposes has to be developed according to specific job functions of engineering specialty (Zhang, 2015). There are some trends in teaching English for specific purposes which are widely used nowadays and allow to study an engineering specialty using foreign language means: simulations method (Silvia, 2012), teaching target technical vocabulary (Nekrasova-Beker et al., 2019), technical translation method (Komochkina \& Selezneva, 2019). The mentioned methods of teaching English aim at incorporating the specifics of an engineering specialty into the course of English. Thus, identifying, studying and practicing the correct use of target technical vocabulary leads to the fulfillment of a specific purpose of a language course.

The successful implementation of the specifics of a specialty into the course of English for specific purposes is possible on the basis of interdisciplinary approach (Maletina et al., 2015). Many scientists made their contribution to the development of the theory of interdisciplinary studies which is worth mentioning since these ideas are the basis for our research. Looking back at the brief history of theory of interdisciplinarity we can mention the following facts. Teacher and philosopher John Amos Comenius stated that 
the goal of learning is the formation of knowledge and skills to solve different problems. A special contribution to the development of the theory of interdisciplinary approach was made by educational reformer Johann Heinrich Pestalozzi, who revealed the diversity of interconnections and relations between academic disciplines. Soviet teachers N.K. Krupskaya, A.S. Makarenko and others began to use interdisciplinary relations at school to prepare students for the future profession. Psychological foundations of interdisciplinary relations were developed by I.P. Pavlov; the scientist assumed that our mental activity is a chain of associations. Soviet psychologist L.S. Vygotsky believed that any development is based on the generalization of the previous ideas and findings. Theoretical research on interdisciplinarity in education began in the mid-20th century. Since then it has been studied and investigated. Nowadays scientists study the interdisciplinarity in almost all areas and spheres. They are involved in research which is at the intersection of different sciences developing courses that bring together a number of adjacent disciplines (Amor, 2014); trying to reach another level in the formation of required qualities (Kozlov \& Shemshurina, 2018); implementing interdisciplinarity in secondary education (Cuervo, 2018); organizing the collaborative work of different major students (Brazile et al., 2018); introducing new disciplines by combining the tools of different subjects (Ertas et al., 2000). The list of researches can be enlarged. Interdisciplinarity is studied from different perspectives providing new results that are successfully introduced into practice.

Although the interdisciplinary approach has been studied for a long time, courses of English are not correctly introduced into an academic curriculum and their possibilities in development of integrated knowledge and skills are not fully considered (Suhodimtseva et al., 2018).

\section{Contradictions}

Development of design and technological documentation is the key step defining the success of the entire manufacturing process. That's why it is crucial to start preparing students to develop technological documentation. According to professional standards, necessary skills when developing design and technological documentation are to be good at professional disciplines and the ability to use English when needed. Thus, the comparative analysis helped us identify the following job tasks that are required to be done to perform job function "Development of design and technological documentation" taking into account professional English skills:

1. Organization of the development of design and technological documentation using instructions in English.

2. Analysis of foreign sources of information and finding useful data.

3. Work with modelling software tools that are developed in English.

4. Making calculations using data in English.

5. Presentation of final results in English. 
Judging from the enumerated job tasks we can say that the ability to perform this job function requires the formation of a competence which consists of skills obtained from different areas which we call integrated knowledge and skills. To gain the competence students need to be taught a few disciplines simultaneously (Vasbieva \& Saienko, 2018; $\mathrm{Xu} \& \mathrm{Liu}, 2015)$. These disciplines are English for specific purposes and some professional disciplines depending on students' major which during their course teach how to work with technological documentation (Alekseeva \& Gumerova, 2018). The goal of teaching these disciplines should be the same - the formation of the competence which represents itself in the ability to perform the enumerated job tasks. Since knowledge from different disciplines will be used to form the competence, the ability to perform the job tasks is the result of application of so-called integrated knowledge and skills. The educational process should be organized differently focusing on the interdisciplinary approach to the study of the disciplines that are responsible for development of the competence. There are some factors that determine the need to use this approach:

- According to professional standards graduates should be able to demonstrate required competences at work which is the ability to use all the gained skills and knowledge from different areas. Any competence is developed on the basis of integrated work, when obtained skills are used to perform different kinds of work.

- English for specific purposes is a discipline which is a combination of two subjects: English and a specific purpose that reflects the study of a professional subject. Thus, two subjects are studied at the same time.

Thus, we can state that there is a contradiction between the interdisciplinary content of an engineering profession when solving professional problems and the existed disciplinary approach to the academic curriculum development (Christe \& Stevenson, 2015; Deshpande et al., 2018; Isoc \& Surubaru, 2020). The stated contradiction can be discussed at different levels:

- At the methodological level: contradiction between an interdisciplinary, integrated approach to the formation of educational standards and the subject-oriented development of curricula.

- At the socio-pedagogical level: contradiction between the need to use the system of acquired integrated knowledge and skills when solving professional problems and graduates' inability to synthesize knowledge from different educational and scientific disciplines when applied in practice.

- At the practical level: contradiction between the need to implement interdisciplinary relations in the educational process and the lack of effective tools for their implementation.

One of the competencies for formation of which an interdisciplinary approach is required is the competence of future technical specialists to perform their job duties using knowledge of a foreign language. According to the traditional disciplinary approach to the development of the educational program, the formation of the 
mentioned competence is usually associated with the study of the discipline "English for specific purposes".

The stated contradictions can be applied to this situation as well and including the specifics of a language discipline the contradictions can be enlarged the following way:

- Contradiction between the special content of assignments that prepare students for professional activities and the insufficient professional readiness of English teachers to help in the implementation of such assignments. To prepare students to use English when solving professional tasks, English should appear in some of their assignments in the study of one professional discipline (Zhang, 2015). Completing a given task using their language knowledge students realize the purpose and application of English and they start developing professional skills when English is used for particular purposes (Komochkina \& Selezneva, 2019). English teachers tend to be incompetent when it comes to choosing a professional assignment and the way it is performed as they do not focus on a real professional purpose of English (Urgal, 2018).

- Contradiction between the interdisciplinary nature of professional tasks solving which a foreign language is used and the disciplinary content of educational tasks prepared for students (Park et al., 2019; Sergeeva et al., 2019). Having analyzed various developed textbooks "English for specific purposes" we come to the conclusion that they do not include any specific professional purpose, because they do not have any material or tasks that can be used performing a real job-related duty. Textbooks tend to focus on the discussion of so-called topics the knowledge of which cannot be applied anywhere outside the classroom.

- Contradiction between the need of establishing interdisciplinary relations between a foreign language for specific purposes and special disciplines and the difficulties of the organization of work between teachers of different disciplines. The work of teachers from different department is not organized at all. Students have to obtain the knowledge of professional English through their English textbooks which are developed by English teachers alone. The organization of work between teachers of different disciplines is a challenging task because it can be done only on the basis of the interdisciplinary approach which requires a lot of work (Othman et al., 2017). Implementation of the interdisciplinary approach consists of such stages, as identification of interdisciplinary relations in one curriculum, development of a plan to establish identified interdisciplinary relations, implementation of interdisciplinary relations in the educational process.

Thus, the mentioned contradictions lead us to the understanding of the entire situation where the problem is how to implement the interdisciplinary approach to the study of English for specific purposes and special disciplines so that students would develop integrated knowledge and skills that could be used in their professional future solving professional problems and performing job functions.

We believe that getting students ready to perform future job functions using the knowledge of English requires development and application of a special course which is designed to help student see how English is used in a professional sphere and can be a 
solution to work related problems. In this paper we focus on the analysis of such course taking into consideration the peculiar use of techniques it involves and problems that student can come across in the educational process. The developed course should be implemented on the basis on the interdisciplinary approach to learning helping students apply the gained knowledge in one discipline to another. Students' ability to transfer their language skills to complete an assignment of other professional disciplines is the ultimate goal of the course.

\section{Creating Professional Environment}

One of the key features of any engineering profession is systemic thinking that is the ability to perceive knowledge, problem comprehensively taking into account every detail and all the variety of possible solutions (Suhodimtseva et al., 2018).

Interdisciplinarity is an approach to the organization of the educational process the ultimate goal of which is to develop systemic thinking for academic and professional purposes (Maletina et al., 2015).

Scientists state that systematic thinking and integrated knowledge and skills can be developed by means of interdisciplinary relations which fall into the following types:

1. Direct academic interdisciplinary relations: knowledge of one discipline is based on the other; such relations are presented in the study of closely related disciplines.

2. Research interdisciplinary relations of problem-solving nature: a few disciplines research the same problem but from different perspectives.

3. Cognitive interdisciplinary relations based on systemic thinking, analysis, imagination, intuition: the same skills are developed by means of different disciplines.

4. Application-based interdisciplinary relations: concepts from one science are used when studying another one.

In our research we focus on the application of cognitive interdisciplinary relations which aim at the development of the stated competence by means of two disciplines: English for specific purposes and one professional discipline. In our research by an interdisciplinary approach we understand a way of teaching when a team of teachers from different departments share information, techniques, and data for the purpose of developing interdisciplinary tasks the practice of solving which will help students gain integrated knowledge and skills that form the required professional competence.

Having analyzed a number of scientific papers on the topic teaching English for specific purposes, we came to the conclusion that before implementing interdisciplinary tasks into practice students need to be prepared and taught some professional English first. This condition is referred to creating particular professional environment in teaching English to technical major students.

Professional environment can be defined as complete organization of studying process, when professional English is taught in accordance with a real job function. The chosen job function is an ultimate purpose of mastering language skills. 
Taking into account cognitive interdisciplinary relations we identify a few distinctive features of professional environment in the context of English for specific purposes:

- total correspondence with the specifics of a major professional discipline;

- all types of work should imitate tasks that students come across when studying their professional technical disciplines (Silvia, 2012).

Creating professional environment we try to teach students to apply different knowledge to another spheres. Professional environment during English classes develops a foreign language competence in a professional sphere.

Development of design and technological documentation is a complex process of various types of work and operations. Design documentation includes a list of documents, for example, drawings and specifications, with the help of which a description of a product or a part or equipment is made. Such documentation contains all the necessary information about future products: how the product is made, its dimensions, manufacturing methods and necessary materials, standard requirements and operating features.

Work with design and technological documentation using the means of a foreign language includes:

- learning special vocabulary consisting of technical terms and abbreviations (Kostadinova \& Tabutova, 2015; Machmud, 2018; Polyakova et al., 2018);

- analyzing foreign sources of technical documentation;

- completing an assigned technical task in a foreign language.

Technical language used when developing design and technological documentation can define the specifics of the entire technical specialty, because as it has been mentioned earlier, design and technological documentation represents all the characteristics of a product or a manufacturing process. Thus, all technical vocabulary that we want to teach within a technical specialty can be mastered developing parts of design and technological documentation.

\section{METHOD}

In this paper we use the following methods of research: on the basis of a review of the scientific literature the analysis of professional activities of engineers in various fields was carried out to identify the need for foreign language skills in order to distinguish integrated knowledge and skills. Application of an expert estimation method among teachers of technical departments of Polytechnic Institute of South Ural State University helped choose a universal and basic job function. A statistical method of applying the Rosenbaum Q criterion to compare and evaluate two independent samples was used to collect data which is presented in the results and findings section.

In this research we investigate the impact of the suggested course developed on the basis of the interdisciplinary approach to the educational process to form a professional 
competence to perform a basic job function of the development of design and technological documentation by means of gaining integrated knowledge and skills. A pedagogical experiment was used to assess the level of students' integrated knowledge and skills. In order to see the positive changes in the level of integrated knowledge and skills students were assigned to complete a test before and after the implementation of the developed course.

\section{Participants}

The participants were five groups of fourth-year students (110 people) of Aerospace faculty of Polytechnic Institute in South Ural State University. The experiment took two years (one academic semester in 2018 and one academic semester in 2019). During the first year two groups of students took part in the experiment, during the second year another three groups joined the experiment. The students are 22-23 years old. Before and after the implementation of the course students' level of integrated knowledge and skills was measured and assessed. The developed course was introduced into their educational program, during a semester these students studied the developed course, they attended English classes and mastered their skills of professional English, and at the end of a semester they were given a task to develop an experimental part of their coursework according to the standards of design and technological documentation using:

- foreign documents and standards written in English,

- tools of modelling software,

- learned technical vocabulary used in documents and standards,

- system of technological documentation development including all its stages.

Students' pieces of work were checked by teachers from two departments. A teacher from an aerospace department was responsible for the organization of students' work. A teacher from a foreign languages department helped students use English properly to avoid any misunderstanding because of language difficulties. Students' readiness to perform the job function "development of design and technological documentation" was assessed on the basis of the scale measuring gained integrated knowledge and skills.

\section{Instruments}

The instruments used in this research were the assigned test to check the level of integrated knowledge and skills to perform the stated job function before and after the course; the developed course.

The assigned test was on the usage of technical terms related to students' major, also students were assigned written and reading tasks and students were interviewed checking their language skills in a professional context. These tasks can be corresponded with the mentioned integrated knowledge and skills the classification of which is presented in results and findings section.

The developed course consists of three modules: 
1. Review of topics corresponding to the studied disciplines of a technical specialty in accordance with the curriculum of a particular specialty, the selected topics are correlated with main professional disciplines, the topics contain major questions of a professional discipline summarizing its content in a foreign language, including basic laws, rules, terms. The purpose of such review of topics is to cover the material of main subjects of a technical major in a foreign language, students learn to perceive and understand the information presented in a foreign language.

2. Vocabulary practice which includes a set of exercises that check the knowledge of learned vocabulary and terms.

3. Complex assignment which is fully integrated with the performance of work in one major discipline as one of the parts of a project or coursework when students develop technological documentation for a necessary product or a process on their own using instructions and guidelines given by teachers from different departments.

It is important to mention the conditions under which the suggested course can be developed the right way and can function successfully:

- students' level of English is not less than intermediate, that is B1-B2 according to Common European Framework of Reference (CEFR);

- English for specific purposes should be taught not only as a separated course, but should be also included in the curriculum of one of professional disciplines where it will be reviewed by students and used when completing some assignments and tasks of this professional discipline;

- interdisciplinary tasks should be developed on the basis of collaboration between teachers from different department.

\section{Data Collection Procedures}

The results showed students' gained level of integrated knowledge and skills divided into two abilities within each integrated knowledge and skill: language literacy and professional skills. The results of the assigned test and the results after the performance of tasks of the developed course were collected by two teachers, associate professors from different faculties: foreign languages and aerospace. The average scores of students' results were used in this research. Taking into consideration changes in the students' level of integrated knowledge and skills before and after the implementation of the course, the entire summary of the results in all five groups was made to prove the effectiveness of the course.

\section{Data Analysis}

The research was carried out based on the idea that the interdisciplinary approach to the educational process, which is realized through the developed course, will help students to gain integrated knowledge and skills to perform the stated job function.

A statistical method of applying the Rosenbaum Q criterion to compare and evaluate results of students' tests was used to analyze quantitative data. 


\section{FINDINGS}

This research presented the impact of the developed interdisciplinary course on the level of integrated knowledge and skills that form a professional competence to perform the stated job function. When one discipline is studied with the help of another, they help understand related problems better and students can easily come up with a complex solution. Studying multiple disciplines by completing interdisciplinary tasks gives a clear understanding of problems and contributes to the development of integrated knowledge and skills.

Students' readiness to perform the job function "development of design and technological documentation" was assessed on the basis of the scale measuring gained integrated knowledge and skills. The results are shown in table 1.

Table 1

Readiness to Perform the Job Function "Development of Design and Technological Documentation" on the Basis of Gained Integrated Knowledge and Skills

\begin{tabular}{|c|c|c|}
\hline $\begin{array}{l}\text { Integrated knowledge and } \\
\text { skills }\end{array}$ & $\begin{array}{l}\text { Students are ready to perform } \\
\text { the job function }\end{array}$ & $\begin{array}{l}\text { Students are not ready to } \\
\text { perform job function }\end{array}$ \\
\hline $\begin{array}{l}\text { 1 Ability to organize the } \\
\text { process of development of } \\
\text { design and technological } \\
\text { documentation using } \\
\text { instructions in a foreign } \\
\text { language }\end{array}$ & $\begin{array}{l}\text { Given instructions are } \\
\text { understood; } \\
\text { documentation is developed } \\
\text { step by step taking into } \\
\text { account all standard } \\
\text { requirements }\end{array}$ & $\begin{array}{l}\text { Instructions are not perceived } \\
\text { the proper way making the } \\
\text { entire work process slow; there } \\
\text { are difficulties with correct } \\
\text { translation of given instructions }\end{array}$ \\
\hline $\begin{array}{l}2 \text { Ability to analyze } \\
\text { foreign sources of } \\
\text { information and find } \\
\text { useful data }\end{array}$ & $\begin{array}{l}\text { Appropriate data and figures } \\
\text { needed to make necessary } \\
\text { decisions concerning the } \\
\text { development of a product are } \\
\text { found }\end{array}$ & $\begin{array}{l}\text { Not all required data is found, } \\
\text { some questions related to } \\
\text { technical developments stay } \\
\text { unanswered }\end{array}$ \\
\hline $\begin{array}{l}3 \text { Ability to work with } \\
\text { modelling software tools } \\
\text { that are developed in a } \\
\text { foreign language }\end{array}$ & $\begin{array}{l}\text { Computer aided tools are fully } \\
\text { used not creating any } \\
\text { difficulties to understand } \\
\text { instructions }\end{array}$ & $\begin{array}{l}\text { Students are not good at using } \\
\text { modelling software in a foreign } \\
\text { language, they cannot do an } \\
\text { assigned task properly since all } \\
\text { tools have to be translated into } \\
\text { Russian, but translation is not } \\
\text { always correct }\end{array}$ \\
\hline $\begin{array}{l}4 \text { Ability to make } \\
\text { calculations using data in } \\
\text { a foreign language }\end{array}$ & $\begin{array}{l}\text { Calculations are performed the } \\
\text { right way; no factual mistakes } \\
\text { are made }\end{array}$ & $\begin{array}{l}\text { Calculations are done with } \\
\text { mistakes leaving the obtained } \\
\text { results to be inaccurate, which } \\
\text { cannot be accepted when } \\
\text { developing technical } \\
\text { documentation }\end{array}$ \\
\hline $\begin{array}{l}5 \text { Ability to present the } \\
\text { final result in a foreign } \\
\text { language }\end{array}$ & $\begin{array}{l}\text { Findings are clearly presented } \\
\text { in a written and oral form }\end{array}$ & $\begin{array}{l}\text { Findings are inaccurate; } \\
\text { presentation is made with } \\
\text { serious mistakes related to the } \\
\text { language use }\end{array}$ \\
\hline
\end{tabular}

International Journal of Instruction, January $2021 \bullet$ Vol.14, No.1 
During the first year two groups of students took part in the experiment. At the beginning and at the end of the semester they were given a test on the usage of technical terms related to their major, also they were assigned written and reading tasks and the students were interviewed checking their language skills in a professional context. These tasks can be corresponded with the mentioned integrated knowledge and skills. In order to see the changes in the level of integrated knowledge and skills we compared the results of the same test before and after the implementation of the course. The results of students' tests were graded according to the stated five abilities within which two aspects were distinguished: language literacy and professional skills. Students could get grades from 2 to 5 (2-bad, 3 -satisfactory, 4-good, 5-excellent) for each of the aspects within each ability. Having collected and graded students' results both before and after the course, we calculated the arithmetic mean of their results for each of the aspects within each ability. To see if the implementation of the course is effective, we compared students' results using the algorithm of applying the Rosenbaum Q criterion to compare and evaluate two independent samples. The results are presented below: table 2 and solution.

Table 2

Arithmetic Mean of Students' Results for Each of the Aspects within Each Ability

\begin{tabular}{lll}
\hline $\begin{array}{l}\text { Integrated knowledge and skills (language literacy }+ \\
\text { professional skills) }\end{array}$ & $\begin{array}{l}\text { arithmetic mean } \\
\text { before the course } \\
\text { (sample 2) }\end{array}$ & $\begin{array}{l}\text { arithmetic mean } \\
\text { after the course } \\
\text { (sample 1) }\end{array}$ \\
\hline $\begin{array}{l}\text { Ability to organize the process of development of design } \\
\text { and technological documentation using instructions in a } \\
\text { foreign language: use of instruction in a foreign language, } \\
\text { knowledge of steps in development of design and }\end{array}$ & 3.1 & 3.7 \\
$\begin{array}{l}\text { technological documentation } \\
\text { Ability to analyze foreign sources of information and find } \\
\text { useful data: work with foreign sources of information, } \\
\text { analysis of technical data }\end{array}$ & 2.8 & 3.4 \\
\hline $\begin{array}{l}\text { Ability to work with modelling software tools that are } \\
\text { developed in a foreign language: understanding of }\end{array}$ & 3.3 & 3.5 \\
$\begin{array}{l}\text { technical terms in a foreign language, } \\
\text { use of modelling software tools }\end{array}$ & 3.2 & 3.2 \\
\hline $\begin{array}{l}\text { Ability to make calculations using data in a foreign } \\
\text { language: understanding of data in a foreign language, } \\
\text { making calculations correctly }\end{array}$ & 3.6 & 4.4 \\
\hline $\begin{array}{l}\text { Ability to present the final result in a foreign language: } \\
\text { use of foreign language communication skills, } \\
\text { presentation of gained results }\end{array}$ & 2.6 & 4.5 \\
\hline
\end{tabular}

\section{Solution:}

1) $\mathrm{n} 1=\mathrm{n} 2=18$

2) Sample 1 -average security values after the course. Sample 2 - average security values before the course

3) The maximum value in sample 2 is 3.6 
4) Calculate the number of values $\mathrm{S} 1$ in sample 1 which are bigger than maximum values in sample $2: \mathrm{S} 1=8$

5) The minimum value in sample 1 is 3.4

6) Calculate the number of values $\mathrm{S} 2$ in sample 2 which are less than minimum values in sample 1: $\mathrm{S} 2=6$

7) Calculate the empirical value $Q$ empirical $=S 1+S 2=8+6=14$

8) Use the table of critical values to find $Q$ critical when $n 1=n 2=18$ and $p=0,01$. $\mathrm{Q}$ critical $=9$

9) $\quad$ Q empirical $=14>\mathrm{Q}$ critical $=9$. Results after the implementation of the course can be considered effective

Having calculated the Rosenbaum Q criterion, we can make a conclusion that the course turned out to be effective and students showed better results doing the same test. After we made sure about the effectiveness of the course during the second year we introduced it to another three groups of students. Implementation of the developed course provided good results and positive growth in students' attitude to the use of English in their professional sphere. The goal of the course was to start developing integrated knowledge and skills, the level of which has significantly risen. The entire summary of the results in all five groups of students comparing the level of integrated knowledge and skills at the beginning of the semester and after implementing the course and completing a final task are presented in figure 1.

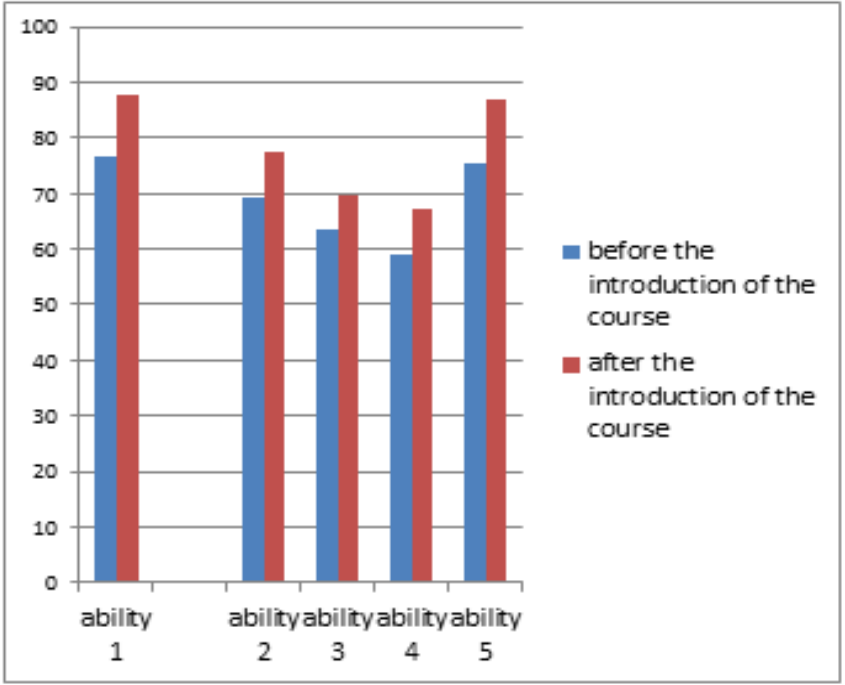

Figure 1

Integrated Knowledge and Skills (Abilities) before and after Introduction of the Course

The statistical significance of the results (development of integrated knowledge and skills) before and after the introduction of the course was tested at the level of significance 0.1 . 
1. Ability to organize the process of development of design and technological documentation using instructions in a foreign language increased by $19.5 \%$.

2. Ability to analyze foreign sources of information and find useful data increased by 26 . $9 \%$.

3. Ability to work with modelling software tools that are developed in a foreign language increased by $31.7 \%$.

4. Ability to make calculations using data in a foreign language increased by $18.4 \%$.

5. Ability to present the final result in a foreign language increased by $25.7 \%$.

The results indicate the successful implementation of the course and its effective use among technical major students, and as a consequence these results show the formation of a sufficient level of students' integrated knowledge and skills that can be developed further to gain the required competence to use English in a professional sphere. The level of 3 out of 5 types of integrated knowledge and skills: ability to analyze foreign sources of information and find useful data has risen significantly; ability to work with modelling software tools that are developed in a foreign language; ability to present the final result in a foreign language. These three types of integrated knowledge and skills can guarantee the performance of the entire job function using the knowledge of English.

Judging by the gained results, we can state that students' increased level of integrated knowledge and skills will allow them to understand professional instructions in a foreign language easily; work on big design projects that require going through steps and preparing standard documentation; find and analyze appropriate, relevant data in the research and development process; use necessary computer-aided tools, perform the required tasks; make calculations in a foreign language using given instruction, authentic information and methods; present the gained results and findings in a foreign language being able to elaborate ideas and proposals. Thus, students are getting ready to perform their job functions using another language as a means of instruction which contributes not only to mastering basic language skills in all its aspects like grammar, listening and comprehension, speaking and writing, but it also contributes to the development of professional skills that can be fully gained only by applying the knowledge of a foreign language to the training process.

\section{DISCUSSION}

It is worth noticing that today many textbooks and teaching material on English for specific purposes have been published and developed, that are a great help when it comes to introduction of common terms and topics to form a general idea about this or that sphere. Moreover, very often such material can be broadly studied by students of different majors for the sake of new information on different topics just as everyone studies business or academic English. The point is such material does not present any practical value for students of some particular major. The specific purpose of English should be of applied nature when students learn how to use the knowledge of English performing job-related tasks. The course of English for specific purposes is not about describing some professions or work, it is about making this work happen. In this paper 
the presented course on the development of design and technological documentation is focused on the acquiring the ability to use integrated knowledge and skills that consist of language literacy and professional skills which shows how English can be mastered within a professional content. Such course is a useful tool to present English for specific purposes. The course develops one professional competence that can be defined as integrative, personal state determining the readiness for a professional activity. Professional competences can be gained by combining knowledge from different areas for the purpose of performing one common task. English for specific purposes is a product of different disciplines brought together.

Authors point out that educational programs for technical major students should be developed paying close attention to the requirements in professional standards (Khairutdinov et al., 2019) and in our study we prove this idea by choosing a real and basic job function the performance of which guarantees the success in completing other professional tasks. The results of this study are in line with the ideas of those researchers who state that English for specific purposes should be taught according to real job functions (Zhang, 2015) and those who introduce the application of such methods as case-study to imitate job function (Isoc \& Surubaru, 2020). Trying to teach students to perform a job function using the knowledge of English there will be common trends in presenting new material which are widely studied and applied in our course as well: simulation method (Silvia, 2012), technical translation method (Komochikina \& Selezneva, 2019).

Scientists note that the successful implementation of the specifics of students' major into an English course can be done using the interdisciplinary approach (Maletina et al., 2015). Some researchers suggest applying the interdisciplinary approach, but focus only on linguistic competence within a professional context (Singh \& Kaur, 2019), but we think that it is not enough when training future engineers because they also need to be taught how to apply this linguistic competence to their future job which can be done by doing some professional tasks. Other authors mention that the interdisciplinary approach can help reach another level in the formation of required professional qualities (Kozlov \& Shemshurina, 2018) which is demonstrated in our course by the increase in the level of integrated knowledge and skills which form a professional competence to use English performing a basic job function. The interdisciplinary approach to the organization of education allows creating suitable educational conditions in order to develop new skills. Thus, the studied researches on the application of interdisciplinarity support this idea. Interdisciplinarity is the main educational tool especially in higher education. All disciplines are to be interconnected in the way they are taught so students would get not only separate theoretical knowledge but practical skills as well. Interdisciplinarity is a basis for education which aims at acquiring and mastering professional competences.

Speaking of studies that state the effectiveness of the communication-oriented learning applying the theory of interdisciplinarity (Rybushkina \& Sidorenko, 2015; Singh \& Kaur, 2019; Kovalyova et al., 2016; Chaikovska et al., 2019), we have arrived at a different conclusion. Focusing only on a communicative competence will not be enough when future engineers are to solve professional problems which are the core of their 
work. Performance of actual job functions depends not only on the ability to communicate; it depends on the ability to use necessary knowledge and skills such as a foreign language to do professional tasks. A foreign language helps to achieve such professional results as manufacturing a new product, implementing a new technology and so on.

Thus, taking into consideration different researches and their points of view, we combine all these suggestions to teaching future engineers. The developed course presents the development of integrated knowledge and skills which contribute not only to the formation of a communicative competence but also to the ability to use English performing a basic job function.

\section{CONCLUSION}

The purpose of the course was to develop a system of integrated knowledge and skills to teach students to transfer acquired language skills to job-related tasks. The suggested approach is a good option of introducing English into a professional sphere of technical major students and building the right set of attitude towards the use of a foreign language in a professional field along with different advantages it has to offer. Integrated knowledge and skills contribute to the formation of the required competence by means of the course. The interdisciplinary approach allows creating professional environment which can be fully realized through such major job function as the development of design and technological documentation. As practice showed, application of language skills developing design and technological documentation as a part of students' coursework defines students' future ability to use knowledge of English at work. Knowledge of English in the process of development of design and technological documentation becomes one of the work performance tools of technical specialists. In this research the interdisciplinary approach to acquiring professional competence by combining tools of two disciplines was studied and implemented. The course demonstrates the way interdisciplinary relations can be made and introduced into practice. The results show that a professional competence consists of a number of integrated knowledge and skills which can be gained through the study of two disciplines together and collaborative work of teachers. Integrated knowledge and skills can be defined as a necessary set of multi-faced tools brought from different areas to serve the same purpose. Thus, the study of multiple disciplines by completing interdisciplinary tasks gives a clear understanding of problems and contributes to the development of integrated knowledge and skills.

The entire summary of the results in all five groups of students comparing the level of integrated knowledge and skills at the beginning of the semester and after implementing the course and completing a final task presents the following results:

1. Ability to organize the process of development of design and technological documentation using instructions in a foreign language increased by $19.5 \%$. Students became better at analyzing and summarizing initial given data in a foreign language, they can go through all steps working out design and technological documentation finding and using appropriate information in a foreign language. 
2. Ability to analyze foreign sources of information and find useful data increased by 26 . $9 \%$. Students are able to work with key vocabulary which helps them understand other more complicated concepts, now they can look for authentic information using such sources as scientific articles, the news, and reports and apply it to their work.

3. Ability to work with modelling software tools that are developed in a foreign language increased by $31.7 \%$. Students became more confident working with different types of software which is developed in English using basic terms and vocabulary; they can easily find the correct explanation or translation if they come across unfamiliar structures or combinations of terms. Students started using modelling software tools more effectively as they understood the principle according to which these tools operate.

4. Ability to make calculations using data in a foreign language increased by $18.4 \%$. Students are able now to think over tasks, problems and produce results in English correctly without making many actual mistakes when calculating or computing.

5. Ability to present the final result in a foreign language increased by $25.7 \%$. Students became more confident English speakers, they can present their findings well and are ready to take part in discussion explaining their ideas, giving extra detail, offering examples, specifying and speculating.

Thus, taking the obtained results into consideration we can say that completing more tasks that the suggested course offers and having more regular practice students are ready to perform the stated job function.

Speaking of implementation suggestions it is worth mentioning that students' level of English shouldn't be less than intermediate, that is B1-B2 according to Common European Framework of Reference (CEFR), all the tasks and assignments can be developed only on the basis of collaboration between teachers from different department: foreign languages department and some technical department.

The suggested course can be used when teaching English to technical major students. The content of the course including topics, key vocabulary and terms can be changed depending on the specifics of a major. The structure of the course remains the same, teaching students how to perform such job function as the development of design and technological documentation is relevant for all technical majors. The development of design and technological documentation is first and foremost step which defines the success of a manufacturing process. Thus, the course can be slightly altered depending on students' specialty and introduced into an educational process.

\section{REFERENCES}

Alekseeva, L., \& Gumerova, D. (2018). Trends to follow in English for specific purposes. Proceedings of 18th International Multidisciplinary Scientific Geoconference-SGEM (pp.321-328). Sofia: SGEM. doi: 10.5593/sgem2018/5.4/S22.041.

Amor, M.C. (2014). The impact of collaboration pedagogy on design concepts and creativity. International Journal of Design Education, 8(2), 37-50. 
Arnó-Macià, E., \& Mancho-Barés, G. (2015). The role of content and language in content and language integrated learning (CLIL) at university: Challenges and implications for ESP. English for Specific Purposes, 37(1), 63-73.

Bhattacharyya, E., \& Zainal, A.Z. (2015). What do students and engineers have to say about communicative competence in technical oral presentations? Pertanika Journal of Social Sciences and Humanities, 23, 123-142.

Bhuvaneswari, R. (2016). Projects for engineers: An innovative approach in English language teaching. International Journal of Applied Engineering, 11(1), 319-321.

Bojović, M., Palurović, L., \& Tica, L. (2015). Communication skills in engineering professions: Communicative language ability in foreign languages. International Journal of Engineering Education, 31(1), 377-383.

Brazile, T., Hostetter Shoop, G., McDonough, C. M., \& Van Citters, D. W. (2018). Promoting innovation: Enhancing transdisciplinary opportunities for medical and engineering students. Medical Teacher, 40(12), 1264-1274

Chaikovska, O., Zbaravska, L., \& Bilyk, T. (2019). Podcasts in teaching EFL for students majoring in engineering. Proceedings of 18th International Scientific Conference Engineering for Rural Development (pp.1915-1920)., Jelgava, Latvia. doi: 10.22616/ERDev2019.18.N344.

Christe, B., \& Stevenson, A. (2015). Engineering curriculum readiness: Implementing an analytical and communication skills building course for the technical disciplines. Proceedings of IEEE Frontiers in Education Conference (pp.1-4). Indianapolis. doi: 10.1109/FIE.2015.7344362.

Clement, A., \& Murugavel, T. (2015). Professional development of English professors in Indian engineering colleges: The need of the hour. Eng Lang Teach, 8(5), 132-142.

Coleman, J. A. (2006). English-medium teaching in European higher education. Language Teaching, 39(1), 1-14.

Cuervo, L. (2018). Study of an interdisciplinary didactic model in a secondary education music class. Music Education Research, 20(4), 463-479.

Deshpande, S., Shesh, A., \& Iyer, B. (2018). English language adoptability in engineering graduates: A case study. Advances in Intelligent Systems and Computing, $810,535-545$.

Dobrydina, T., Kersh, N., Kononova, V., Shipilova, T., \& Usvyat, N. (2019). On developing transversal competences of modern engineers for coal mining emerging. E3S Web of Conferences, 105, id.04032. doi: 10.1051/e3sconf/201910504032.

Ertas, A., Tanik, M. M., \& Maxwell, T. T. (2000). Transdisciplinary engineering education and research model. J of Integrated Design and Process Science, 4(4), 1-11.

Fiorito, L. (2019). English for special purposes as a research field: From practice to theory. International Journal of Language Studies, 13(4), 43-54.

Gluchmanova, M. (2017). Creation of e-courses in English for students of production technology. TEM Journal, 6(3), 613-617. 
Goldman, A. A., Ivanova, R. P., \& Zarovnyaeva, S. S. (2019). Cognitive approach to teaching English to diamond mining engineers. Gornyi Zhurnal, 2, 97-99.

Grevtseva, G. Y., Marina, V. T., Balikaeva, M. B., Kashina, I. S., \& Kotlyarova, I. O. (2019). Conditions for teaching professional competence of future electronics engineers in digital technology. Proceedings of International Conference "Quality Management, Transport and Information Security, Information Technologies" (IT\&QM\&IS) (pp.490493)., Sochi, Russia.

Isoc, D., \& Surubaru, T. (2020). engineering education using professional activity simulators. In M. Auer, \& T. Tsiatsos (Eds.), The challenges of the digital transformation in education. ICL 2018. Advances in intelligent systems and computing, vol 916 (pp.520-531). Springer.

Khairutdinov, R. R., Safin, R. S., Korchagin, E. A., Mukhametzyanova, F. G., Fakhrutdinova, A. V., \& Nikishina, S. R. (2019). The content of educational programs in technical universities: Quality of applying the modern professional standards. International Journal of Instruction, 12(1), 357-360.

Kim, J., Kim, E. G., \& Kweon, S.-O. (2018). Challenges in implementing Englishmedium instruction: Perspectives of humanities and social sciences professors teaching engineering students. English for Specific Purposes, 51, 111-123.

Kogan, E. A., \& Krymskaya, O. B. (2018). Problems in studying English language among future engineers. Vysshee Obrazovanie v Rossii [Higher Education in Russia], 27(7), 45-51.

Kolomiets, S., Medvedeva, E., \& Perevalova, A. (2019). Mining engineers training: Case study method. E3S Web of Conferences, 105, id.04033. doi: 10.1051/e3sconf/201910504033.

Komochkina, E. A., \& Selezneva, T. V. (2019). Long live technical translation: Technical translation in English language. Vysshee Obrazovanie v Rossii [Higher Education in Russia], 28(6), 107-114.

Kostadinova, D., \& Tabutova, E. (2015). Teaching English technical terminology. Journal of Language and Literature, 6(2), 280-289.

Kovalyova, Y. Y., Soboleva, A. V., \& Kerimkulov, A. T. (2016). Project based learning in teaching communication skills in English as a foreign language to engineering students. International Journal of Emerging Technologies in Learning, 11(4), 153-156.

Kozlov, A. V., \& Shemshurina, S. A. (2018). Fostering creativity in engineering universities: Research activity and curriculum policy. International Journal of Instruction, 11(4), 93-106

Machmud, K. (2018). Technology-integrated ESP (English for specific purposes) instructions: the engineering students' perspectives. Asian ESP Journal, 14(1), 443-448.

Maletina, L., Karmanova, Y., \& Kashpur, V. (2015). Implication of interdisciplinary team teaching of an ESP course. Mediterranean J of Social Sciences, 6(5), 556-561. 
Mulyadi, D., Hersulastuti, \& Purnama, Y. (2019). Students' perceptions of blended learning in mastering English for specific purposes. Journal of Physics: Conference Series, 133, 012116. doi: 10.1088/1742-6596/1339/1/012116.

Nekrasova-Beker, T., Becker, A., \& Sharpe, A. (2019). Identifying and teaching target vocabulary in an ESP course. TESOL Journal, 10(1), art. e00365.

Niyazova, A. Y., Mussagozhina, A. K., Kabdenova, A. B., Lukpanova, A. E., \& Kozhakanova, M. T. (2018). Modeling learning situations of verbal communication in professionally-oriented teaching English for students in the sphere of transport Logistics. XLinguae, 11(2), 190-205.

Othman, Z., Wahi, W., Ya'Acob, A., \& Kofli, N.T. (2017). A collaborative ESP: 'engineering specific purpose' of workplace English. Journal of Institutional Research South East Asia, 15(2), 18-30.

Park, S.-Y., Choi, Y.-R., Jang, S.-O., \& Shim, Y.-S. (2019). Study on the content-based instruction on English for specific purpose. International Journal of Innovative Technology and Exploring Engineering, 8(3), 316-320.

Ph'ng, L. M., Ming, T. S., \& Nambiar, R. M. K. (2016). Match or mismatch: Teaching styles and learning styles in an ESP classroom. Social Sciences, 11(12), 2977-2982.

Polyakova, L. S., Yuzakova, Y. V., Suvorova, E. V., \& Zharova, K. E. (2018). Peculiarities of translation of English technical terms. IOP Conf. Ser.: Mater. Sci. Eng. 483, 012009. doi: 10.1088/1757-899X/483/1/012009.

Rybushkina, S. V., \& Sidorenko, T. V. (2015). Modular approach to teaching ESP in engineering programs in Russia. Proceedings of International Conference on Interactive Collaborative Learning (pp.105-108). Firenze, Italy: Institute of Electrical and Electronics Engineers Inc.

Rynearson, A. (2010). Collaborative learning in engineering and English: A new approach. Paper presented at the Joint International IGIP-SEFI Annual Conference, Tmava, Slovakia.

Salehi, H., Davari, A., \& Md Yunus, M. (2015). English language needs analysis of qur'anic sciences and tradition students in Iran. English Language Teach, 8(6), 50-56.

Semchuk, N., Lykhova, S., \& Demianenko, U. (2019). Using English as a foreign language when teaching subjects of the criminal law cycle. Asia Life Sci, 2, 517-534.

Sergeeva, M. G., Zotov, V. V., Tsibizova, T. Y., Skovorodkina, I. Z., \& Tereshchenko, A. G. (2019). Technology of integrated foreign language teaching at university. International Journal of Engineering and Advanced Technology, 8(6), 4586-4592.

Silvia, C. (2012). The impact of simulations on higher-level learning. Journal of Public Affairs Education, 18(2), 397-422.

Singh, D., \& Kaur, G. (2019). Professional communication skills in English for nonnative English speaking engineers: Challenges and a proposed teaching framework. International Journal of Recent Technology and Engineering, 8(2), 595-599. 
Smagulova, B. G., Tussupbekova, M., Zagatova, S. B., Kazhikenova, N. K., \& Zhamankozova, A. T. (2019). CLIl approach to overcome language acquisition barrier of non-linguistic specialty students. Int J of Innov, Creativity and Change, 8(6), 1-12.

Suhodimtseva, A. P., Vorozheikina, N. I., \& Eremina, J. B. (2018). Integration approach to solving problems of interdisciplinary nature in the conditions of post-industrial education. In D. B. Solovev (Ed.), Smart technologies and innovations in design for control of technological processes and objects: Economy and production (pp.501-510). Springer.

Tarasova, E. (2016). Professional English teaching on the basis of blended learning. Asian EFL Journal, 2, 79-85.

Anthony, L. (2018). Introducing English for specific purposes. New York: Routledge.

Triawan, F., Biddinika, M. K., Hanaoka, S., Takahashi, F., \& Aziz, M. (2019). Promoting global education in science and engineering: An experience in Indonesian high schools. Journal of Physics: Conference Series, 1175, 012167.

Urgal, C. C. (2018). The key role of foreign language teachers in content and language integrated learning at a university level. Int J of Learning in Higher Educ, 25(2), 7-16.

Vasbieva, D. G., \& Saienko, N. V. (2018). Exploring students' perception and efficiency of technology-mediated ESP teaching. XLinguae, 11(1XL), 127-137.

Voloshina, I. A., \& Kotlyrova I. O. (2017). Elite engineering education in mixed project groups. Proceedings of the 14th International Conference Efficiency and Responsibility in Education (pp.528-535). Prague, Czech Republic.

Woźniak, M. (2017). Esp in CLIL degree programmes. ESP Today, 5(2), 244-265

Wyatt, M., Hassan, A., Anderson, A., \& Young, D. (2018). Supporting first-year undergraduate Emirati engineers in reading in English for science. Asian ESP Journal, 14(1), 33-62.

$\mathrm{Xu}$, J., \& Liu, H. (2015). Research on teaching methods for the course English for petroleum engineering. World Transactions on Engin and Techn Edu, 12(2), 159-163.

Yelubayeva, P., Chaklikova, A., \& Asmatullayeva, N. (2016). Critical discourse analysis in developing vocational English context. European Journal of Language Policy, 8(2), 209-223.

Yemelyanova, Y. V., Avazbakiyeva, F. R., Ibrayeva, A. B., \& Aikenova, A. Z. (2016). The necessity of English for specific purposes at the law universities of the republic of Kazakhstan. International Review of Management and Marketing, 6(3), 9-16.

Zhang, L. (2015). Design of English teaching in engineering majors: Oriented toward specialty. World Transactions on Engineering and Technology Edu, 13(4), 561-565. 